\title{
On Inheritance of the Sublime: From Longinus to Burke
}

\author{
YUE Jian-feng \\ Shanghai Jiao Tong University, Shanghai, China
}

\begin{abstract}
As great philosophers and aesthetes who have significant influence on the ushering and development of the term "sublime", both Longinus and Edmund Burke have their respectively elaboration on sublime that not only has inner connection but some sheer difference. The aim of this thesis is to interpret the inheritance of Burke to Longinus through the comparison between their attitudes on sublime through doxologie of comparative literature, and it mainly focuses on the point of view, major concern, composing elements and interconnecting aesthetic essence between them.
\end{abstract}

Keywords: sublime, inheritance, aesthetics, Longinus, Burke

Longinus (213-273) is the very first thinker who comes up with the term "sublime" in his treatise, and in his great work On the Sublime, he elaborated how to achieve the sense of sublime in literature works and five elements of sublime language and so on. His thoughts on the aesthetics of sublime are so unique and grand thus he left an everlasting effect on later generation. The later generation who had been his admirers and followers included Edmund Burke (1729-1797) and Immanuel Kant (1724-1804). Edmund Burke depicts his aesthetics thoughts on sublime in his great work A Philosophical Inquiry into the Origin of Our Ideas of the Sublime and Beautiful. And Kant discusses his understanding in the concept "sublime" in his The Critique of Judgment. But they both have their own thinking and distinct features which are so different from that of Longinus, and they respectively forms into Burkean empiricist model and Kantian formalist (idealist) model, however, there is still some connection between their thoughts.

And in following passages, the definition of sublime Longinus and Burke will be discussed, centering at Burke's transforming the definition of sublime from a positive, grand and passionate image as well as the criteria of "true value of literature" is that "a really great bears a repeated examination" into Burke's depiction from the aspect from reader's experience that "Whatever is fitted in any sort to excite the idea of pain and danger, that is to say, whatever in any sort terrible, or is conversant about terrible objects, or operates in a manner analogous of terror, is the source of sublime". ${ }^{1}$ From this, it could be learned that Longinus and Burke are both genetically alike and different. This article aims to go some way to investigating more closely how the relationship between Burke and his predecessor Longinus can be read.

At present, a thorough analysis of their inheriting relationship on the subject of sublime has not yet been carried out, and this article aims to go some way to investigating more closely how the relationship between Burke and his Greco-Roman predecessors can be read.

\footnotetext{
YUE Jian-feng is a Ph.D. Candidate who majors in British and American literature in Shanghai Jiao Tong University. ${ }^{1}$ Ferguson, Frances, Solitude and the Sublime: Romanticism and the Aesthetics of Individuation. London: Psychology Press, 1992.
} 
Alexander Pope highly praised Longinus in his Essay on Criticism: “Thee, bold Longinus, all the Nine inspire. And bless their critic with a poet's fire, as well as the ardent judge, being zealous in his trust. With warmth gives sentence, yet is always just; Whose own example strengthens all his laws. And is himself the great Sublime he draws."2 From this superb highly compliment the high position of Longinus in the literature critize field is so clear. Although Longinus' name and the author of the great work even the date are still in doubt, but the significance of the work has already arrived at a widely accepted consensus. Longinus' center question lies in what kind of literature work can be referred as a good one and how the sense of sublime can be achieved. By the word "sublime" Longinus, means elevation or loftiness-all that raises style above the ordinary, and gives it distinction in its widest and truest sense. So sublimity is a certain distinction and excellence in composition. Longinus says that, both nature and art contribute to sublimity in literature. Art is perfect when it seems to be nature, and nature hits the mark when she contains art hidden within her. He came up with five ways to achieve the sense of sublime in literature works.

Firstly, as his greatest saying has revealed: "Sublimity is the echo of greatness of soul." ${ }^{2}$ It can be inferred that no sublime work can be produced unless the author himself or herself own a thought of grandeur. For these whose life is full of mean and narrow ideas can no admirable and sublime words produces. "It is natural that great accents should fall from the lips of those whose thoughts have always been deep and full of majesty." ${ }^{2}$ As Longinus mentioned and quoted in the book, only great mind like Homer, Plato and Demosthenes even the Bible can transfer their innate high powers into the passages. From this aspect, Longinus' fancy about classicalism can be easily found out that Longinus does not restrain himself only to Greek legend, but to any work with grand beauty of cosmology, to make it into universal beauty of sublime.

Secondly, Longinus specially stresses the great significance of being capable of strong, forceful and passionate emotion. He asserts that only genuine emotion can contribute to the loftiness of the tone. As he said in On the Sublime, "I would confidently affirm that nothing makes so much for grandeur, as true emotion in the right place, for it inspires the words as it were, with a wild gust of mad enthusiasm and fills them with divine frenzy." 2 and the emotion should be true and faithful.

Thirdly, the source of sublime is to achieve excellence in style and the use of speech. Figures of speech should not be used mechanically; rather they must be rooted in genuine emotion. Used naturally, they impart elevation to style, and are them made more effective by an elevated style. The grandeur of any figure will depend on its being employed in the right place and the right manner, on the right occasion, and with the right motive.

Forth, Longinus depicted diction as the forth source of sublime which including choice and arrangement of words, as well as the use of ornamental language. Although this part is unfortunately lost, we can still learn that a suitable and striking word adopted at right place has a moving and lasting power on the readers. Finally, there is elevated and dignified composition. ${ }^{2}$

These entire elements he has come out reflect the combination of art and nature ${ }^{3}$ in literature work, that is to say, On the Sublime is not a pure work of aesthetics, but more likely one of literary criticism from the viewpoint of creating. And he was praised as first "romantic critic”3 for his much emphasis on imagination, ecstasy and transport. "Longinus has marked out grounds of criticism very far from those of the ancient period

\footnotetext{
2 Pope, Alexander, Essay on Criticism. Cambridge: Cambridge University Press, 2013.

3 Pres, Terrence Des, (1983), Terror and the Sublime. Human Rights Quarterly, 5(2), 135-146.
} 
generally, further still from those which were occupied by any critic (except Dante) of the Middle Ages and the classical revival, and close to, if not in all cases overlapping the territory of the modern romantic criticism itself."

Thus from this point of view, it can be found out that Longinus ushers the beginning of romantic criticism. He is also the first literature critic who transfers his attention from the then popular focused outer reality. In total, we may say that Longinus write this work to solve the problem how to achieve the sense of sublimity in literature work, that is to say, he offered advice on the basis of literature creating. "But I maintain that this will be found to be otherwise if it be observed that, while nature as a rule is free and independent in matters of passion and elevation, yet is she wont not to act at random and utterly without system.” Here he elaborated the relation "spur" (nature) and "curb" (art). And Longinus repeatedly stress the importance of appropriate amount in both "nature" and "art"; on the one hand, an over-dose emphasis on the thoughts of "sublime" nature will result in "turbidity", "puerility" and "unreasonable and empty passion”. On the other hand, too much pursuit of novelty in the expression of idea, namely, over-fancy about new and innovative forms leading to not only success but also the other end.

Edmund Burke is the most outstanding and important representative of British empirical aesthetics. He is the first one who totally applied empirical philosophy into the research of aesthetics, which reveals the tendency of materialism in British aesthetics. No matter from the elaboration on a series of terms or the methods of research, Burke is the one who drew conclusion from British empirical aesthetics. More importantly, since the publication of his A Philosophical Inquiry into the Origin of Our Ideas of the Sublime and Beautiful and Lessing's translation, Burke became the first thinker who distinguishes the two different terms "beauty" and "sublime" and this great work became the most important document on the elaboration of sublime between Longinus' On the Sublime and Kant's The Critique of Judgment.

One important thing is that Burke develops sublime from a literature style of Longinus to an independent aesthetic category that parallel to the category "beauty". Burke is the very first man who strictly distinguishes sublime from beauty and depicts their distinct features respectively. Also he makes deep and detailed analysis into the biological and psychological base of the sense of sublimity. Burke left a great influence on the whole psychological system of Kant.

As Zhu Guangqian mentioned in the 15th chapter of his Literary Psychology that besides beautiful and ugly, there are another two pairs of contrary terms_-"tragedy" and "comedy", "sublime" and "beautiful". Sublimity overwhelms us with giant body and grand spirit, the first thing we feel is irresistible power which will make us feel terror and thrill, further giving us a feel of inferiority, and furthermore a sense of dignity. And human beings will be inspired and delighted by himself or herself being elevated to a height of sublime. Thus it can be concluded that in the progress of achieving the sense of sublime in one's mind, it generally turns from unpleasant to greatly delight. These two fields together illustrate the complicity of aesthetics.

Burke's thoughts started his thinking from the angle of readers and audiences. The very first chapter comes up with a discussion on the "taste", and that is a reader's response to certain literature work or experiencers to outer world. Burke mainly focuses on what kind of things can invoke sublime in the mind of readers. "But there is not the same obvious concurrence in any uniform or settled principles which relate to taste" ${ }^{\prime 4}$, since the taste of every human being is so different that it can be known that this discussion is oriented

${ }^{4}$ Zhu Guangqian, Literary Psychology. Hefei: Anhui Education Press, 1996. 
from the point of view of readers, which forming into a contrast with Longinus' literature creative viewpoint on the subject of sublime.

And, for Burke, the most plain and nature emotion for people are pain and happiness, which he believes have strong and influential effect on people. Burke researched sublimity from one's subjective experience which sublime usually reflected in a sense of being terrified. When one's heart is absorbed in serious horror, he can think about nothing because of being occupied and thus has no time to pay attention to other objects. Thus the great and irresistible power of the sublime does not come from logic reasoning but the force so strong that one merely has time to reason. Suffering and pain is the foremost outcome of the sublime, then admire and respect.

Burke holds that the following characters can help to achieve the sense of sublime: Firstly, sublime objects are vast in their dimensions, which is also the most distinct difference between the sublime and the beautiful objects $^{5}$. Once added some ideas that of contingency and painful, the object would become more magnificent. Liking overlooking from the edge of a cliff is much more terrified than looking up from the bottom, thus overlooking entails more sense of sublime than looking up. Secondly, another character of sublime object is dark and gloomy and obscure, which is necessity to make the danger more painful and mysterious, as the dark nights always make us trembling. John Milton often adopts obscure or gloomy force in his poetry to from into a sense of mystery of dangerous objects. No matter in nature or in poetry, an obscure, gloomy, uncertain image can result in a more sublime feeling than a clear and stable one. Thirdly, a sublime object is the variant of some force. But if it is a useful force, and being beneficial for happiness and enjoyment, it's far from being sublime. The most representative force is the power of God, we can never ignore the horror of the irresistible nature force no matter His justice conviction or mercy. Fourthly, another source of sublime is infinity, which has tendency to make one both delighted and terrified and that is the most truthful effect of sublime. The infinite and continuing extend to one direct leads to unlimited imagination, like the pillars in ancient Roman temple and corridors in church, which both achieve the effect of sublime by the means of continuing infinity.

Except the main characters mentioned above, some other sublime characters Burke came up with includes empty, innocence, loneness and silence, difficulty such as hard work which needs much strength and labor, the sound of thunder, storm or cannon and the sudden start or stop of forceful sound and so on. Sublime objects include not only natural objects and phenomenon, but the artificial, social phenomenon even artist work. From all Burke's elaboration on sublime, we put much emphasis upon the function of imagination. He believed that imagination is indispensable from terror and all the function of sublime should be released through imagination.

There has not been a systematic study of the relationship between Burke's Philosophical Enquiry and his Greco-Roman predecessors. References are made to the influence of Plato, and in particular Longinus, but they tend to be cited as a general influence and point of departure. ${ }^{6}$ A thorough analysis would be carried out in following paragraphs about how the once rhetorical handbook leaving such a great impact on Burke.

Samuel Monk once said: "Burke simply did not discuss Longinus", 7 for Burke only refer to Longinus twice in Philosophical Enquiry. But it can be found that as a literature critic, but it cannot overthrow the

\footnotetext{
${ }^{5}$ Ryan, Cressida, Burke's Classical Heritage: Playing Games with Longinus. The Science of Sensibility: Reading Burke's Philosophical Enquiry. Netherlands: Springer, 2012, pp. 225-245.

${ }^{6}$ Ryan, Cressida, Burke's Classical Heritage: Playing Games with Longinus. The Science of Sensibility: Reading Burke's Philosophical Enquiry. Netherlands: Springer, 2012, pp. 225-245.

7 Monk, Samuel Holt, The Sublime: A study of Critical Theories in XVIII-Century England, 1935.
} 
conclusion that there is sheer connection of inheritance despite their different attitudes on the sublime. Because Burke is quite carefully about his adoption of references and quotation and he barely uses any quotation from ancient or contemporary writers. This is quite different from that of Longinus, who quotes much from Homer, Plato and the Bible though we cannot find much obvious traces of Longinus in Philosophical Enquiry.

And Monk summarizes the situation as follows: "In a sense, the study of the eighteenth-century sublime is the study of the Longinian tradition in England, although, as may be supposed, the student will be led far away from the Greek critic's views.” One sheer difference of Longinus and his predecessors is their aims while Longinus combines much approaches and content of Plato, Aristotle and Horace. He gets rid of their different focuses, eliminates Plato's pessimistic view on inspired poet and their creative passion.

According to Longinus, greatness of soul was the central source of the sublime in literary art, and its chief effect on the reader was spiritual transport-a sense of being uplifted, of being carried beyond oneself as if one shared in or had indeed become sublime. "The naive sublime may be lofty, noble or grand; but nowhere is it said to touch upon terror.” Longinus even remarks that some passions-pity, grief and fear in particular cannot be sublime, which forms into a sharp contrast with Burke's attitude.

As Russell and Winterbottom put it, "Longinus looks at literature as a whole, and not for its own sake". This inspiration and yearn for a grand heart and sublime literature work will also leave mark on Burke. Burke expanded the aspect of passion in Longinus and marginalizes or even ignores the other aspects. In Longinus' On the Sublime, passion is not listed in the five sources that I've mentioned in Chapter 2. In Longinus' treaties, he put the passion at a place, which is parallel to nature. He clearly illustrated that passion is so important that can spur men's inspiration to create, which is similar to psychic ability of poetry and the magic of poetic language in Plato's Ina and Republic. So we may find out that Longinus and Burke give different significance to passion.

Another difference lies in their different approach towards tragic pleasure. The origin of tragic pleasure is always a quite disputable issue through Western aesthetics history. One effective theory is that why we can get delight from tragedy is because of its fictional essence. The French writer Fontenelle, Bernard le Bovier de believes in it, too. He holds that since a tragedy is fictional story that the audience can release and lessen the miserable feeling for the characters and adjust it according to their own needs, to which degree it can became a kind of delight. And David Hume also mentioned the same point of view in his On Tragedy. And Zhu Guangqian holds that there is a sheer difference between the tragic experience in actual life and literature tragedy, and tragedy is artist work watching tragedy an aesthetic experience. ${ }^{9}$ Since aesthetic experience is distinct and spontaneous we just devote ourselves wholeheartedly into the tragedy and we forget about making real-life judgment, instead, we just enjoy it as a passionate drama. Tragedy in real life will surly causes our pity and compassion but the tragedy literature work can wipe out our compassion and pity and sympathy thus making it into enjoyment and delightful. For Longinus, he listed much quotation from Homer's tragedy, with grand sense, passionate emotion, a sense of sublime is thus created, which can brought people a feeling being elevated and lifted, furthermore tragic pleasure is created. But for Edmund Burke, he holds that those nonfictional and real tragedies and people's misfortune will also moves and delights us. No sovereignty is comparable to the tragic pleasure created by the loss of Troy. No matter a historical one or a real-life and eye-watching one, can both move and delight us, but the distinguish lies in imitation. Burke believes that the

\footnotetext{
${ }^{8}$ Russell, Donald Andrew, \& Michael Winterbottom (Eds.), Classical Literary Criticism. Oxford: Oxford University Press, 1998.

9 Zhu Guangqian, Literary Psychology. Hefei: Anhui Education Press, 1996.
} 
closer a tragic literature work to real life, the more delight it can causes. From these above we can infer that Burke is strongly influenced by Longinus on this issue and further develop it into details.

The most disputing question along the developing process of the sublime of Longinus, Burke or even later Kantian focus is that the relationship between the object and its sublime effect-between the object taken to arouse heightened response and the affective quality of such a response-is so variously conceived. On one hand, the power of sublime objects is so forceful that it must can manipulate and control the object; on the other hand, the root or the ultimate goal of sublime is to rise an intense self-presence and exaltation, sometimes even self-transcendence. Longinus stresses on the latter one that the passionate feeling of being sublime in one's inner heart while Burke holds that the sublime originates from the characters of objects themselves and leave tint on one's mind.

Doxologie is the research about the fame and influence of a certain literature work, writer or a literature movement in another country or writer, the reaction and innovation during the process of transmission. There are various influencing factors such as the mentality of writer, the writing device or skill, the artist image depicted in the work, the major theme, major literature movement and so on and so forth. As to Longinus and Burke, Burke was mainly influenced by the artist image sublime that Longinus has created, as the classical Faust, which has been interpreted by Christoper Marlowe as Doctor Faust, and by Goethe, and also interpreted into musical works such as A Faust Symphony (1854) by Franz Liszt. The sublime image that Longinus has created in his treaties leave a deep impact upon Burke through its grand surrounding and high spirits, and Burke especially deprived his passion and particularly heightened it in his elaboration.

Longinus and Burke, both masters in the field of aesthetics, and Longinus especially being well-known for his firstly creating the term "sublime", Burke firstly distinguished the term "sublime" and "beautiful" and make deep analysis into them. Although they have much difference in their emphasizing-Longinus mainly illustrates the approaches towards how to achieve a sublime literature work and one who is not gifted can still make equal achievement with a balance of "nature" and "art", "spur" and "curb"; while Burke mainly distinguishes the form of "sublime" and "beautiful”, providing another aesthetic pair besides "beautiful" and "ugly". And it is well-acknowledged that Kant is more apparently influenced by Burke, but there is still much clear connection between Longinus and Burke about "sublime”. Burke deprives the element "passion" from On the Sublime and more detailed explanation on it while marginalizing the other ones. What's more, as for tragic pleasure, Burke further develops Longinus' "elevated- delighted" system more detailed with some addition of comparison between nonfictional and fictional tragedy. In a word, Burke still draws much from Longinus' attitude on sublime in many aspects.

\section{References}

Ferguson, Frances. (1992). Solitude and the Sublime: Romanticism and the Aesthetics of Individuation. London: Psychology Press.

Monk, Samuel Holt. (1960). The Sublime: A Study of Critical Theories in XVIII-Century England. Michigan: University of Michigan Press.

Pope, Alexander. (2013). Essay on Criticism. Cambridge: Cambridge University Press.

Pres, Terrence Des. (1983). Terror and the Sublime. Human Rights Quarterly, 5(2).

Russell, Donald Andrew, \& Michael Winterbottom. (Eds.). (1998). Classical Literary Criticism. Oxford: Oxford University Press. Ryan, Cressida. (2012). Burke’s Classical Heritage: Playing Games with Longinus. The Science of Sensibility: Reading Burke's Philosophical Enquiry. Netherlands: Springer.

Zhu Guangqian. (1996). Literary Psychology (文艺心理学). Hefei: Anhui Education Press (安徽教育出版社). 